\title{
A STUDY OF THE PURCHASING MANAGEMENT SYSTEM WITH RESPECT TO TOTAL QUALITY MANAGEMENT
}

\author{
Javier GONZÁLEZ-BENITO* \\ Departamento de Administración y Economía de la Empresa \\ Universidad de Salamanca \\ Campus Miguel de Unamuno, s/n. Edificio FES \\ 37007 Salamanca \\ Spain \\ Tel: 923-294500 ext. 3509 \\ Fax: 923-294715 \\ javiergb@usal.es
}

\author{
Angel R. MARTÍNEZ-LORENTE \\ Facultad de Ciencias de la Empresa \\ Universidad Politécnica de Cartagena \\ Paseo Alfonso XIII, 50 \\ 30203 Cartagena (Murcia) \\ Spain \\ Tel: 968-325618 \\ Fax: 968-325435 \\ Barrie G. DALE \\ Manchester School of Management \\ UMIST \\ PO Box 88, Manchester, M60 1QD, UK \\ Tel: 01612003424 \\ Barrie.Dale@umist.ac.uk
}

* Corresponding author

Date of submission: May $10^{\text {th }}$, 2001

Resubmission: April 17 ${ }^{\text {th }}, 2002$ 


\section{Biographical notes of authors:}

Dr. J. González-Benito has a degree in Mathematics from the University of Salamanca (Spain), where he joined as a lecturer in Management after taking the MPhil degree in Management Studies of the University of Cambridge (UK) and the MSc degree in Operations Management of UMIST (UK). He has published articles in journals such as: International Journal of Production Economics, International Journal of Operations and Production Management, International Journal of Production Research, European Journal of Purchasing and Supply Management, and Management Decision.

Dr. A. R. Martínez-Lorente has a degree in Business from the University of Murcia (Spain), where he got the doctorate in business with a thesis on TQM. He is assistant professor in Operations Management in Polytechnic University of Cartagena (Spain). He has published articles in journals such as: International Journal of Operations and Production Management, International Journal of Production Research and Quality Management Journal. He is member of the Editorial Advisory Board of International Journal of Quality and Reliability Management.

Prof. Barrie Dale is Head of School in the Manchester School of Management, UMIST and is Rotating Research Professor at Erasmus University, Rotterdam. He has been carrying out research into quality management for over 20 years and has produced 10 books and some 350 papers on the subject. During this time he has obtained funding of over £4M to pursue a range of projects in the area of quality management. He is co-editor of the International Journal of Quality and Reliability Management and Editor of the McGrawHill 'Quality in Action' book series. 


\title{
A STUDY OF THE PURCHASING MANAGEMENT SYSTEM WITH RESPECT TO TOTAL QUALITY MANAGEMENT
}

\begin{abstract}
One of the key elements of a TQM policy is the assurance of an adequate supply of materials and components. The objective of this paper is twofold. Firstly, it analyses the relationship between different purchasing system variables and supplier quality assurance practices. Secondly, it explores both the connection between supplier quality assurance practices and other quality assurance practices used for internal processes and examines the relationship of such practices with supply operational results. Different hypotheses are tested using data obtained from a sample of 152 Spanish automotive components suppliers. This data shows clear evidence of the importance of product, supplier and company characteristics and highlights the importance of a company-wide commitment to the application of quality assurance principles.
\end{abstract}

\section{KEY WORDS}

Quality assurance, supply chain management, total quality management, purchasing function

\section{INTRODUCTION}

During the last two decades, the subject of quality management has received the attention of a considerable number of researchers who have analysed the concept from a number of angles [1-2]. In the literature, it is possible to find diverse constructs, which are aimed at assessing the degree of implementation of TQM recommendations and guidelines [3-5], papers that relate TQM implementation with company results [6-8] and papers that relate company characteristics with TQM implementation [9-10]. 
The relationship with suppliers has been identified by researchers as one of the factors that define TQM policy and practice $[3-5,11]$. This paper reports the main findings of a study which has analysed the relationship of purchasing system variables with quality management measures and operational results of the purchasing function.

The paper is organised into five main sections. Section 2 provides a critical analysis of literature relating to purchasing and supply management, leading into the specific study objectives and the hypothesis that are proposed. Sections 3 and 4 comment upon the methodology for testing such hypotheses and presentation of results and the discussion of findings respectively. The main conclusions of the research study are summarised in Section 5 .

\section{TOTAL QUALITY MANAGEMENT IN PURCHASING AND SUPPLY}

One of the key elements of a TQM policy is the assurance of an adequate supply of materials and components of the right quality, at the right time and which constitute value for money. According to writers such as Leonard and Sasser [12] it is difficult to achieve the required quality standards without the appropriate raw materials and components. In a TQM approach to managing a business, suppliers should be chosen according to their quality and reliability and not just price. For example, Garvin [13] found that plants whose suppliers were ranked by quality rather than cost minimisation outperformed those plants where cost minimisation was the primary objective.

Developing long-term partnership relationships with suppliers is another important factor in a TQM purchasing policy [14], the benefits of which have been extensively reported by Womack et al. [15] and Lamming [16]. According to Burnes and Dale [14] and Ishikawa [17], other characteristics of a supply chain management system include:

- Intensive communication with suppliers

- A willingness by both parties to improve the relationships

- Collaboration with suppliers to solve problems to the advantage of both parties

- Reducing the number of suppliers 
- The supplier making a contribution to the customer's design process

Another important feature in the customer-supplier relationship is the fulfilment of the ISO 9000 quality management system series requirements [18]. Corrigan [19] and Hockman et al. [20] point out the importance of ISO 9000 series certification in competing in global markets, although they also criticise the standard as time consuming and expensive to apply.

The application of TQM to the purchasing function have been analysed by Carter and Narasimhan [21] and Lascelles and Dale [22]. They found several advantages of this, including implementation of best practice through benchmarking activities, identification of areas for improvement through quality management methodologies, application of quality management systems, tools and techniques, and improved team working. But they also identified the following problems:

- Poor levels of communication between purchaser and supplier

- Inadequate supplier quality improvement processes

- Suppliers' lack of confidence and trust in the purchaser

This paper reports an analysis on the variables related to a TQM approach within the purchasing function. These variables have been divided into three groups: product characteristics; company characteristics; and supplier characteristics (see Figure 1). These factors explain the degree to which TQM principles, in particular quality assurance principles, are adopted in supply management.

In such an examination there are many product, company and supplier characteristics which should be analysed ${ }^{1}$. In this research, only seven characteristics have been selected for study. This selection, that was based on the literature review and includes those variables identified from existing research, is very much subjective; other researchers may have different views on this selection process. Thus, this paper should therefore be considered as a first attempt to identify the determinant factors of the implementation of TQM principles

\footnotetext{
${ }^{1}$ The interaction model of the IMP group [23-24] provides a detailed list of factors that should be taken into account when supply relationships are analysed. This model explicitly shows the importance of environmental and organisational factors for the development of an interaction process between supplier and buyer and the existence of a particular atmosphere. It also reveals the importance of product characteristics.
} 
to the purchasing function. Many other studies would be necessary to provide a complete snapshot of the contingencies conditioning such an implementation process.

A second objective of the research was to analyse the effect of supplier assurance practices on supply operational results, which, as indicated in Figure 1, is hypothesised as positive. Nonetheless, the purchasing function is embedded into the whole organisation and the implementation of quality assurance principles to supply activities cannot be treated as an isolated initiative. The research took into account the efforts of companies to implement such principles within the organisation. In the paragraphs what follow each of the elements in figure 1 are commented upon in relation to the different hypotheses.

-- TAKE IN FIGURE 1 --

\section{Product Specific Factors}

Product type is a decisive factor of the production system and this can affect the selection of the purchasing system. Three product characteristics were chosen for analysis: product technological complexity; product essentiality; and the relative value of purchases in the product.

Technological complexity is frequently related to the existence of specific assets in the relationship [25] and, according to Transaction Cost Economics [26], if technological complexity is high the company will be more inclined to co-operate with their suppliers in a attempt to establish governance structures which are closer to vertical integration. Furthermore, highly complex products have a greater probability of defectiveness than is the case with simpler products. For example, in complex products, the number of components is likely to be larger, the tolerance intervals will be smaller, components are manufactured from high specification and complex to work materials, and they are likely to be produced in small batches. Thus, it is expected that companies will insist on applying exhaustive quality systems and checks to the acquisition of technologically complex 
products to minimise the risk of introducing defective components into the assembly of the final product. Thus, the following hypothesis is proposed:

H1: The higher the percentage of technologically complex products purchased by a company, the greater the implementation of supplier quality assurance practices.

Purchased materials are considered to be essential if part or all the production processes are stopped when they are not available. Materials of this type cannot be assembled outside of the production line and no other processes can be undertaken whilst waiting for their arrival from the supplier. It is therefore important to assure the supply of this class of material since non-conformances will result in production disruptions which will increase the level of costs. This variable is specially important in Just-in-Time environments, where inventory levels are low and the assurance of quality is a key issue for success [27]. This reasoning leads to the following hypothesis:

H2: The higher the percentage of 'essential' materials purchased by a company, the greater its implementation of supplier quality assurance practices.

The importance of supply chain management can be assessed by the value of the expenditure incurred when acquiring materials and components from suppliers. The higher the relative value of purchases, the greater the attention which needs to be paid to procurement activities and, therefore, the stronger the emphasis put on quality assurance. The total value of final products is the sum of purchase value and the value added by the company. The relative value of purchases is inversely related to the relative value added, which has been frequently used to measure vertical integration [28]. Thus, the higher the value of purchases, the lower the degree of vertical integration and, therefore, the higher the dependence on external resources. The risk of such dependence can be mitigated by quality assurance practices. Thus:

H3: The higher the economic value of the purchases of a company, the greater its implementation of supplier quality assurance practices.

\section{Company Specific Factors}


According to Benson et al. [9] and Martinez-Lorente et al. [10] TQM application is not independent from company characteristics. Factors such as size and organizational structure affect the degree of TQM application. In the study described in this paper, two company variables have been analysed: size by number of employees, and the degree of internationalisation.

Large companies have considerable negotiating power over suppliers since their volume of purchases constitutes attractive and essential business. Therefore, it is easier for them to convince or make it a contractual requirement that suppliers: (i) develop a quality management system which meets the requirements of the ISO 9000 series, AS 9000 or TL 9000; (ii) use a set of quality management tools and techniques within a specific problem solving methodology; (iii) put into practice the basics of an advanced quality planning system; and (iv) face up to the initial investments and maintenance expenditures that these practices involve. On the other hand, managers of small companies have received less training on TQM than their large counterparts (see [29-30]). Well-trained managers who are more frequently found in larger companies, have a better knowledge and understanding of quality management and, as pointed out by Benson et al. [9], management knowledge is related positively to the application, thereby indicating that TQM methods, practices and approaches are more readily understood and applied in large companies. This leads us to the following hypothesis:

H4: The larger the size, by number of employees, of a company, the greater its implementation of supplier quality assurance practices.

Quality is one of the key elements to company survival in global markets. The internationalisation process and multinational success is, to a great extent, driven by a strong commitment to quality so that quality assurance and improvement practices are applied company-wide. Caddick and Dale [31] warn that those companies operating in more than one country should be especially aware of the importance of quality and that they can speed up the implementation of new practices by the transfer of experiences, practices and knowledge between plants in different national and international locations. Accordingly, the following hypothesis is proposed: 
H5: Company internationalisation is related to the implementation of supplier quality assurance practices.

\section{Supplier Specific Factors}

Collaboration with suppliers accounts for the success of many quality initiatives involved with supply chain management. The characteristics of suppliers can affect the extent to which this collaborative climate is achieved and, hence, the implementation of relevant underpinning activities; according to Dale [11], the two important variables are supplier size and supplier specialisation.

Some researchers have found a relationship between company size by number of employees and, TQM implementation [10] whilst others have found this not to be the case [9]. From a supplier perspective, size is related to the human and economic resources which are needed to cope with new challenges. Furthermore, large suppliers who are not inclined to collaborate with their customers have sufficient power and independence to resist such overtures. The relationship between supplier size and TQM implementation could indicate whether or not suppliers believe in the benefits of TQM or are simply going along with the application to satisfy their customers. Thus, the following hypothesis is proposed:

H6: Supplier size, by number of employees, is related to its implementation of supplier quality assurance practices.

If a supplier is fully dedicated to an industrial sector, it will be more inclined to adapt practices which characterise that sector. Car assemblers, for example, have well developed quality management practices and are leaders in the generation of new manufacturing trends and lean manufacturing concepts [32-33]. Although Western assemblers seem to lag behind Japanese ones, the differences are being reduced [34-35] and it can be considered that they show great concern about quality assurance practices. Those suppliers who are specialised in manufacturing automotive components find it relatively easy to migrate to the practices applied by their customers and to adapt their own supply chains to the model followed in the industry. However, those suppliers who are non-specialised in the automotive industry would probably find it not cost-effective to implement certain practices 
which are considered as standard but not given the same attention outside the industry. Consequently, those companies with suppliers who are completely devoted to the production of automotive components would find fewer barriers to change within their supplier communities. This leads us to propose:

H7: Supply industry specialisation is related to its implementation of supplier quality assurance practices.

Integrated quality assurance and supply operational results

A company with TQM expertise would ensure that a quality assurance programme for supply activities is carried out in parallel to similar practices for internal activities. That is, quality assurance initiatives have usually a company-wide focus. Thus, a positive relationship can be expected between external (i.e. supply related) and internal quality assurance practices, (i.e. production-related). Consequently, the following hypothesis is proposed:

H8: The implementation of supplier quality assurance practices is positively related to internal quality assurance practices.

It is expected that the implementation of supplier quality assurance and management practices has a positive effect on the operational results of the purchasing function [36-38]. This effect can arise in the form of higher reliability, since the company reduces unexpected stoppages in the production process due to non-conforming materials. It can also appear in the form of flexibility, since through effective quality assurance practices stock levels can be reduced and response to market needs can be speeded up. Of course, this effect can also appear in the form of improved quality, reducing the number of defective products that reach the market and improving performance. In addition, these effects also lead to reduced costs since expenses on activities such as the reworking of defective products, inventory maintenance, the disposal of defective and unrecoverable products would be lower, as well as the consumption rates of inputs. Using this reasoning, the following hypothesis is proposed: 
H9: The greater the implementation of supplier quality assurance practices, the better the operational results of the purchasing function.

However, most of the benefits derived from the implementation of supplier assurance practices can only have a limited impact if similar principles are not applied within the factory. An integrated approach in which the quality of supplies and intermediate products are considered equally important would yield considerable benefits. In this way, flexibility, cost reduction, quality and reliability would be further improved and the purchasing function would experience more benefits from its activities. Thus, the following hypothesis is proposed:

H10: The operational results of the purchasing function will be improved if supplier and internal quality assurance practices are implemented together.

\section{METHODOLOGY}

This paper is part of an extensive research programme which has examined the implementation of advanced supply practices in the Spanish automotive components manufacturing industry. A database of 397 manufacturers with more than 40 employees has been created from diverse sources ${ }^{2}$. A questionnaire comprising of some 100 questions was designed and tested with 10 companies before being transmitted to the purchasing managers of these manufactories. To encourage a good response, preliminary and followup phone calls were made to the companies. A total of 152 (38\%) fully completed questionnaires were returned, which constitute the empirical base for the work reported in this paper. The number of employees of these 152 companies ranged from 40 to 4500 , with $80 \%$ comprising between 80 and 700 employees.

\footnotetext{
${ }^{2}$ The sources used were:

- $\quad$ Repertorio de Fabricantes Españoles de Equipos y Componentes de Automoción 97 (Spanish Auto Components Producers Directory), published by the Spanish Institute of Foreign Trade (Instituto Español de Comercio Exterior, ICEX)

- $\quad$ List of companies associated with ODETTE (http://www.odette.es)

- $\quad$ Dun\&Bradstreet 1998 database of the 50000 largest Spanish companies

- $\quad$ List of suppliers given by some assemblers
} 
According to the literature, a TQM policy for the purchasing function encompasses different practices that range from supplier collaboration to the participation of suppliers in product design and development. In order to collect all these attributes of supplier quality assurance, a group of eleven questions were selected from those which measured the implementation of diverse advanced supply practices (see first eleven practices in Table 1). Several measuring instruments have been developed in the literature $[3,4,5,6]$ to assess the effectiveness of internal quality assurance. However these instruments are too extensive to be included in this questionnaire and, hence, five single questions were selected. These encompass several of the main TQM internal dimensions as described in the literature: the general philosophy (continuous improvement), the workforce management (quality circles, multi-skilling of workers) and process flow management (statistical quality control, productive maintenance) (see the latest five practices in Table 1).

In order to reduce the number of measures, exploratory factor analysis with OBLIMIN rotation was applied to the 16 items. The pattern matrix (Table 1) shows the existence of five correlated but differentiated factors with eigenvalues $>1$. The five internal quality assurance practices load in the first factor whereas the other items load in the remaining four factors. These results prove that internal assurance practices can be considered as a separate dimension and supports the idea that advanced supply practices include different interrelated dimensions (see González-Benito et al. [39] and González-Benito and Spring [40] for a multidimensional conception of advanced supply practices). Thus, the first factor was taken as a single measure of internal quality assurance practices. The second and third factors measure the existence of co-operative attitudes, the fourth factor measures the application of quality control practices (inverse scale) and the fifth factor measures the degree of involvement of suppliers in design and development activities (inverse scale). Factors 2, 3, 4, and 5 contains distinctive features of a TQM approach to supply management, but none of them, by itself, provides a complete measure. Thus a summated scale of these four factors was used to build a single measure of the implementation of supplier quality assurance practices.

The exogenous factors considered in the hypotheses have been measured with single questions; Table 2 shows the content of these questions. All the variables except purchase value and company size are categorical, however apart from company internationalisation, 
verbal frequency scales have been used as for statistical purposes they can be considered interval and ordinal [41].

-- TAKE IN TABLE 1 --

-- TAKE IN TABLE 2 --

To measure the operational results of the purchasing function, each manager was asked to assess according to a five-point scale, if he/she feels his/her company to be: very inferior (1); somewhat inferior (2); equal (3); somewhat superior (4); or very superior (5) to its competitors with regard to 8 specific questions which influence performance (e.g. product design). These questions were selected to be related to the basic objectives of operations management: quality, speed, dependability, flexibility and cost [42]. These 8 items were reduced to a single measure through principal component analysis (Table 3). Reliability (Cronbach's $\alpha$ ), according to Flynn et al. (1990) is acceptable since it exceeds 0.7, with most of the item loadings exceeding 0.4 , and with many of them at 0.6 ; the resulting factor is able to explain more than $33 \%$ of the variance.

-- TAKE IN TABLE 3--

\section{DISCUSSION OF FINDINGS}

Hypotheses 1 to 7 . Factors related to supplier quality assurance practices.

The first stage of the analysis was to study the relationships between the seven exogenous factors (i.e. technological complexity, essentiality, value of purchases, company size, company internationalisation, supplier size and supplier specialisation) included in the hypotheses. All the factors will be commented upon together as they have been subjected to similar analyses.

Table 4 shows the Spearman correlation tests for those variables which can be considered as ordinal. With respect to the binomial variable -company internationalisation- ANOVA tests have been conducted to compare the means of each variable in the two groups: 
internationalised and non-internationalised companies. A number of significant relationships have been found - the connection between supplier size, value of purchases and between technological complexity and essentiality; and company size and supplier specialisation. It is logical that those companies who purchase a considerable proportion of the final product value tend to look for large suppliers in an attempt to achieve supply stability. It is also reasonable to accept the essentiality of complex parts since they are frequently the core of the final product. Companies whose purchases have high levels of technological complexity tend to be large, mainly because they have a number of specialised functions and workforce and have active Research and Development, and Design activities with appropriate levels of investment. Furthermore, complex components tend to be manufactured by specialised suppliers because they have the necessary industry specific knowledge. Internationalised companies tend to purchase more technologically complex products and to buy a larger part of their products, they are also likely to be larger and have large specialised suppliers.

\section{-- TAKE IN TABLE 4 --}

Collinearity is notable and multiple regression analysis does not, a priori, seem to be an appropriate method to test the hypotheses. Thus, the variables have been studied separately, taking into account their correlation with the dependent variable (i.e. the implementation of supplier quality assurance practices). Table 5 shows such correlation indexes except for company internationalisation, for which the method is not applicable. It can be seen that five variables (i.e. technological complexity, essentiality, value of purchases, supplier size, and supplier specialisation) are significantly correlated with the implementation of supplier quality assurance practices. The role of technological complexity and suppliers specialisation is specially important.

\section{-- TAKE IN TABLE 5 --}

To provide additional evidence of the importance of each variable and, since most of them can also be considered categorical, the means of supplier quality assurance implementation for each one of the categories have been compared through ANOVA tests, see Table 5 and Figure 2. The variables 'purchase value' and 'company size', originally ordinal variables, have been transformed to categorical variables. The former has been used to define four 
groups of companies: those purchasing more than $65 \%$ of the final value of their products, between 51 and 65\%, between 36 and 50\% and less than $36 \%$ of the final value of their products. The latter has been transformed to a five-point scale distinguishing companies: with more than 1000 employees; between 500 and 999; between 250 and 499; between 100 and 249 and between 50 and 99.

\section{-- TAKE IN FIGURE 2 --}

The means are significantly different $(\mathrm{p}<0.10)$ for six of the variables (i.e. technological complexity, essentiality, value of purchases, company size, supplier specialisation and company internationalisation). With respect to product specific characteristics, the data supports the hypotheses, with technological complexity appearing as the most important factor. The graphical representation shows an increase in quality assurance practices as technological complexity increases. Changes are not so evident for essentiality, where the most important difference occurs between the 45 companies whose purchases are judged as essential and the remaining 107 companies. In the case of purchase value, there is a clear difference between companies purchasing more than 50\% of their products' final value and those purchasing less than this amount. This could be considered as the threshold at which companies become more concerned with matters of quality assurance.

With regard to company specific variables, the importance of internationalisation is clear. Those companies with a global presence show special concern about quality assurance and its management and have introduced a number of relevant practices. The relevance of company size is not as clear. Although ANOVA tests reveal certain levels of significance, correlation is low and there is not the degree of evidence as for the other variables. Thus, although the data supports the hypothesis, additional research is required to examine this in more detail.

With respect to supplier specific characteristics, a supplier base specialised in automotive components stands out as a frequent partner of supplier quality assurance initiatives (both correlation and ANOVA test confirm the importance of supplier specialisation, $\mathrm{p}<0.01$ ). This is not surprising since it was the automotive and electronics industry which had to respond, by way of improved quality, from the mid 1970s onwards to the threat of Japanese imports. In addition, there has been considerable inward investment by the Japanese in the 
Western automotive industry. The relevance of supplier size is not supported in the analysis; although correlation is statistically significant $(\mathrm{p}<0.01)$, the ANOVA test is not. The means graphically represented in Figure 2 behave according to the hypothesis, however the differences are not significant.

In summary, the data shows clear evidence of the relationship of five variables (i.e. technological complexity, essentiality, value of purchases, company internationalisation, and suppliers specialisation) with the implementation of supplier quality assurance practices. Thus, hypotheses 1, 2, 3, 5 and 7 are confirmed. Whilst the analyses leads to the view that the size of the company and their suppliers by number of employees is also related to quality assurance practices, there is a lack of agreement between the two statistical tests applied and this points to the need for further research.

The previous analyses have provided evidence of the relevance of different variables, but, due to collinearity, it is not possible to know whether they relate to the implementation of supplier quality assurance practices directly or indirectly through correlation with other variables. Statistics cannot sort out this causality problem, although they do reveal which factors explain the most variance of the dependent variable and, therefore, which factors are able to explain things that the other factors are not able to show. In this respect, stepwise multiple regression analysis has been applied with the seven variables commented upon as independent variables (see Table 6). Three of them have entered the regression $(p=0.05)$ and each column in the Table contains one of the three consecutive steps. The order in which the variables are introduced in the new step of the regression depends on their capacity to explain the remaining variance.

The final model is statistically significant $(\mathrm{p}<0.01)$ and explains $35.8 \%$ of the variance of the dependent variable (see $\mathrm{R}^{2}$ ). The most explicative variable is technological complexity, followed by supplier specialisation; they share most of the predictive power. Company internationalisation also enters the regression but only explains a very small part of marginal variance (it increase $\mathrm{R}^{2}$ from 0.327 to 0.358 ). It is also worth pointing out that the three elements considered in the analysis (i.e. products, company and suppliers) are able to explain the implementation of supplier quality assurance practices. Thus, these three groups of variables should be taken into account in any future research. 
Hypotheses 8 to 10. Relationships between supplier and internal quality assurance practices and supply operational results.

Both measures of quality assurance (i.e. supplier and internal) present a correlation of 0.367, which, according to the Pearson test, is statistically significant $(\mathrm{p}<0.01)$. In this sense, the data confirms hypothesis 8 and supports the existence of a relationship between supplier and internal quality assurance practices. A company concerned with quality assurance will undergo transformations in supply management as well as in its internal processes and practices. For example, if SPC is implemented to a company's internal key processes and benefits accrue from this then it will encourage its suppliers to examine the use of SPC.

To test hypothesis 9, which anticipate a relationship between the implementation of supplier quality assurance practices and the operational results of the purchasing function, multiple regression analysis was conducted. The measure for supply operational results was introduced as the dependent variable and the measures for implementation of supplier quality assurance practices and company size were considered as independent variables, the company size being treated a control variable. The resulting model (see the second column in Table 7) is statistically significant $(\mathrm{p}<0.01)$ and able to explain $19.2 \%$ of the variance of supply operational results. Whereas the effect of the control variable (company size) is not significant, the implementation of supplier quality assurance practices present a positive and significant coefficient, which provides the evidence to confirm hypothesis 9 (i.e. a positive relationship between quality assurance practices and supply operational results).

Hypothesis 10 considers the role of the implementation of internal quality assurance practices on the relationship studied in hypothesis 9. It is anticipated that supply operational results will be boosted if supplier quality assurance practices are supported by internal quality assurance practices. To test such an effect, the measure for the implementation of internal quality assurance practices was introduced as another independent variable in the multiple regression analysis conducted to confirm hypothesis 9. The resulting model (see column three in Table 7$)$ is again statistically significant $(\mathrm{p}<0.01)$ and able to explain 
$24,9 \%$ of the variance of supply operational results. Both, supplier and internal quality assurance practices, register a positive and significant effect on the dependent variable. This means that, in spite of the significant correlation between these two independent variables, both are able to explain part of results that the other variable is not able to explain. That is to say, there is a direct effect of internal quality assurance practices on supply operational results in addition to the indirect effect through their correlation with supplier quality assurance. In other words, if internal quality assurance practices are lacking the operational results of the purchasing function will be lower. Thus, there is some evidence of the complementarities between supplier and internal quality assurance practices and hypothesis 10 is confirmed.

-- TAKE IN TABLE 7 --

\section{CONCLUSIONS}

Eight of the 10 hypotheses tested have been confirmed. It has been found that 5 variables technological complexity, product essentiality, purchase value, company internationalisation and suppliers specialisation- are positively related to the level of application of supplier quality assurance practices. This confirms previous research findings [9-10], indicating that quality practices are not independent of company and sector characteristics. The managerial implications arising from the study are set out in the text. It is suggested that management teams study the 10 hypothesis in relation to their company characteristics and purchasing and quality assurance practices. From this gap analysis they will then be able to generate areas for improvement.

All the product determinant factors show a relationship with the application of supplier quality assurance practices, which indicates that companies do not give the same degree of importance to the quality of all their products. The underlying explanation for this is that some managers still identify quality assurance practices with an increase in costs and only apply them to what they consider to be their most important products and when under pressure from demanding customers. This can be considered as a short-term practice which is contrary to the philosophy of TQM. It also demonstrates a lack of belief in the concept and strongly suggests that more education is needed amongst Spanish management teams. 
Company internationalisation is also related to the implementation of quality assurance practices, indicating that companies who operate globally place more reliance on such practices. However, a clear relationship has not been found between company size and application of quality assurance practices, contradicting the findings of Martinez et al. [10]. This may be explained by the fact that quality management is getting more widely known within Spanish organisations. This conclusion can not be considered to be necessarily true in small companies since the sample was mainly related to medium to large sized organisations.

There is a lack of a clear relationship between supplier size and quality assurance activities, indicating that, although their size could help them collaborate with the purchaser, their greater negotiation power and independence gives them the flexibility to choose the purchasers with whom they deal. This indicates that suppliers perhaps do not have sufficient confidence in the benefits of quality management systems for the supplier-client relationship. This finding is confirmed by the fact that specialisation, which is a measure of dependence of the supplier from the purchaser, is related to the application of supplier quality assurance practices. When the customer's power over the supplier is greater, the supplier will collaborate with respect to matters of quality and when this power is smaller, the supplier will not be as co-operative. This lack of collaboration from suppliers can provide further explanation to the finding that different quality assurance practices appear to be applied to different products. In the situation in which suppliers are not disposed to collaborate, companies make more efforts to 'persuade' their suppliers. That is to say, the cost of negotiating, for example, the application of an ISO 9001 norm by the supplier is only compensated when the cost of receiving non-conforming supplies is perceived to be high.

The data not only shows that supplier and internal quality assurance practices are mutually related but that supplier quality assurance practices are positively related with supply operational results and that this positive relationship is reinforced by the application of internal quality assurance practices. This finding provides further evidence of the interest in applying quality management theories and can be used by managers to justify their efforts to assimilate and apply these practices. 
Total Quality Management is still relatively immature in Spanish manufacturing companies and the findings from this study bear this out. It is clear that management teams are taking a minimalist approach to TQM and, as a consequence, are not committing the appropriate resources and, therefore, are not reaping the full benefits. This is evident in relation to the finding of applying different levels of quality assurance practices to different products. All the research and practical evidence points to the fact that this is not a good practice to follow and is a characteristic of what Dale [43] classifies as an "uncommitted" organisation. It is therefore essential that bodies such as the European Foundation for Quality Management and the Spanish Association for Quality set about educating management on the benefits of TQM.

The study is not without limitations. The data are perceptual and, hence, ideas subjective, with all the associated problems which this brings. Future studies including objective data would enrich the analysis. Further work should be undertaken to include data not considered in this study. In particular, additional elements of product characteristics (e.g. raw materials or components), company characteristics (e.g. production system -batch, job shop, ...-) and supplier characteristics (e.g. supplier seniority as a measure of confidence) should be considered. It would also be useful to analyse the differences between different industries, as this study has been limited to the automotive components industry. Longitudinal research to consider the time lags of the effect of supplier quality management practices on performance would also be of value. 


\section{REFERENCES}

[1] Amoako-Gyampah K, Meredith JR. The operations management research agenda: an update. Journal of Operations Management 1989; 8(3): 250-262.

[2] Pannirselvam GP, Ferguson LA, Ash RC, Siferd SP. Operations management research: an update for the 1990s. Journal of Operations Management 1999; 18(1): 95-112.

[3] Ahire SL, Golhar DY, Waller MA. Development and validation of TQM implementation constructs. Decision Sciences 1996; 27(1): 23-56.

[4] Flynn BB, Schroeder RG, Sakakibara S. A framework for quality management research and an associated measurement instrument. Journal of Operations Management 1994; 11(4): 339-366.

[5] Saraph JV, Benson PG, Schroeder, RG. An instrument for measuring the critical factors of quality management. Decision Sciences 1989: 20(4): 810-829.

[6] Anderson JC, Rungtusanatham M, Schroeder RG, Devaraj S. A path analytic model of a theory of quality management underlying the Deming management method: preliminary empirical findings. Decision Sciences 1995; 26(5): 637-658.

[7] Choi TY, Eboch K. The TQM paradox: relations among TQM practices, plant performance, and customer satisfaction. Journal of Operations Management, 1998; 17(1): 59-75.

[8] Flynn BF, Schroeder RG, Sakakibara S. 1995. The impact of quality management practices on performance and competitive advantage. Decision Sciences 1995; 26(5): 659691.

[9] Benson PG, Saraph JV, Schroeder RG. The effects of organizational context on quality management: an empirical investigation. Management Science 1991; 37(9): 1107-1124.

[10] Martinez-Lorente AR, Gallego-Rodríguez A, Dale BG. Total quality management and company characteristics: an examination. Quality Management Journal 1998; 5(4): 59-71.

[11] Dale BG. Total quality management: an overview. In Dale BG, editor. Managing quality, third edition. Oxford, Herts: Blackwell Publishers, 1999. p. 3-33.

[12] Leonard FS, Sasser WE. The incline of quality. Harvard Business Review 1982; 60: 163-171.

[13] Garvin DA. Quality on the line. Harvard Business Review 1983; 61: 74-75.

[14] Burnes B, Dale BG. Working in partnership: Best practices in customer-supplier relations. Hants: Gower Press, 1998.

[15] Womack JD, Jones DT, Roos D. The machine that changed the World. New York: Macmillan, 1990.

[16] Lamming R. Beyond partnership strategies for innovation and lean supply. New Jersey: Prentice Hall, 1993. 
[17] Ishikawa K. What is total quality control? The Japanese way. New Jersey: Prentice Hall, 1985.

[18] Kekre S, Murthi BPS, Srinivasan, K. Operating decisions, supplier availability and quality: an empirical study. Journal of Operations Management 1995; 12(3-4): 387-396.

[19] Corrigan JP. Is ISO 9000 the Path to TQM?. Quality Progress 1994; May: 33-36.

[20] Hockman KK, Grenville R, Jackson, S. Road Map to ISO 9000 Registration. Quality Progress 1994; May: 39-42

[21] Carter JR, Narasimhan R. The role of purchasing and materials management in total quality management and customer satisfaction. International Journal of Purchasing and Materials Management 1994; 32(4): 2-12.

[22] Lascelles DM, Dale BG. The buyer-supplier relationship in total quality management. Journal of Purchasing and Materials Management 1989; 25(3): 10-19.

[23] Ford D, editor. Understanding Business Markets: Interaction, Relationships, Networks, 2a edición. London: Dryden, 1997.

[24] Håkansson H, editor. International Marketing of Purchasing of Industrial Goods. Hampshire: John Wiley and Sons, 1982.

[25] Bensaou BM, Anderson E. Buyer-Supplier Relations in Industrial Markets: When Do Buyers Enter The Trap of Making Idiosyncratic Investments? Working Paper 97/27/TM/MKT, INSEAD, 1997.

[26] Williamson OE. Markets and Hierarchies. Analysis and Antitrust Implications. New York: The Free Press, 1975.

[27] Roy RV, Guin KK. A Proposed Model of JIT Purchasing in an Integrated Steel Plant. International Journal of Production Economics 1999; 59(1-3): 179-187.

[28] Suominen SI. The Measurement of Vertical Integration. E.A.R.I.E. Conference, Budapest, 1989.

[29] Dale BG, Duncalf AJ. A study of quality assurance in small businesses. I Mech E Proceedings 1984; 198B (6): 135-139.

[30] Prapopoulos M, Dale BG. An examination of the application of the UMIST quality improvement framework. I Mech E Proceedings 1995; 209B(3): 277-285.

[31] Caddick R, Dale BG. Sourcing from less developed countries: a case study. Journal of Purchasing and Materials Management 1987; 23(3): 17-23.

[32] Krafcik JF. Triumph of the Lean Production System. Sloan Management Review 1988; 30(1): 41-52.

[33] Womack JP, Jones DT, Roos D. The Machine that Changed the World: The Triumph of Lean Production. New York: Rawson Macmillan, 1990.

[34] Harwit E. Japanese Management Methods and Western Investment in Eastern Europe. Columbia Journal of World Business 1993; 28(3): 46-61.

[35] Helper SR, Sako M. Supplier Relations in Japan and the United States: Are They Converging?. Sloan Management Review 1995; 36(3): 77-84. 
[36] Larson PD, Kulchitsky JD. Single sourcing and supplier certification: performance and relationships implicatitons. Industrial Marketing Management 1998; 27(1): 73-81.

[37] Stuart FI, Mueller P. Total quality management and supplier partnerships: A case study. International Journal of Purchasing and Materials Management 1994; 30(1): 14-20.

[38] Vokurka RJ. Supplier partnerships: A case study. Production and Inventory Management Journal 1998, First Quarter: 30-35.

[39] González-Benito J, Spring M. JIT Purchasing in the Spanish Auto Components Industry: Implementation Patterns and Perceived Benefits. International Journal of Operations and Production Management 2000, forthcoming.

[40] González-Benito J, Suárez-González I, Spring M. Complementarities Between JIT Purchasing Practices: An Economic Analysis Based On Transaction Costs. International Journal of Production Economics 2000, forthcoming.

[41] Flynn BB, Sakakibara S, Schroeder RG, Bates KA, Flynn EJ. Empirical Research Methods in Operations Management. Journal of Operations Management 1990; 9(2): 250-284.

[42] Slack N, Chambers S, Harland C, Harrison A, Johnston R. Operations Management. London: Pitman Publishing, 1995.

[43] Dale BG. Managing Quality (Third Edition). Oxford: Blackwell Publishing, 1999. 
Figure 1

Research framework

Company characteristics:

$$
\text { - SIZE }
$$

- INTERNATIONALISATION

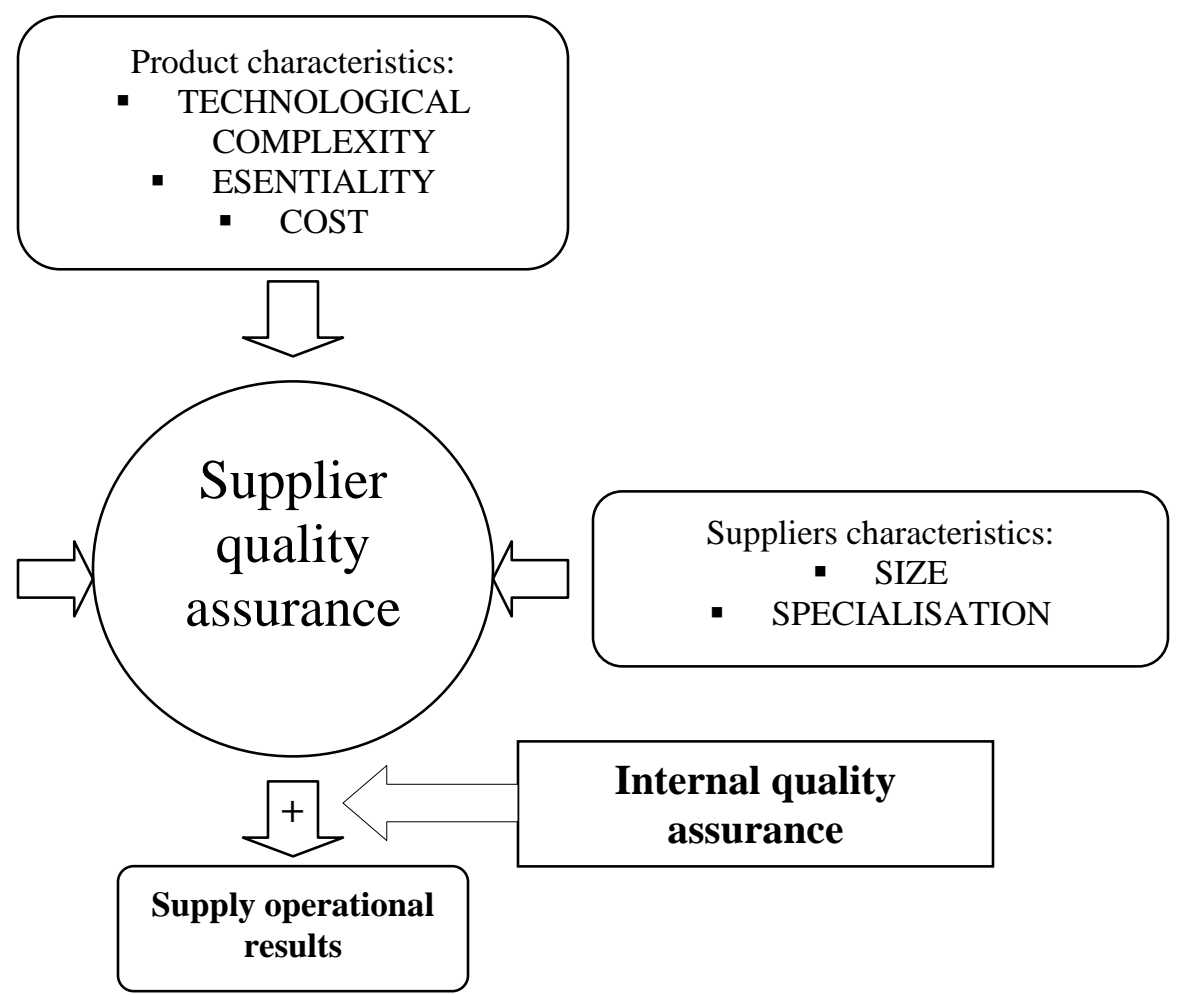


Figure 2

Supplier quality assurance by determinant factors
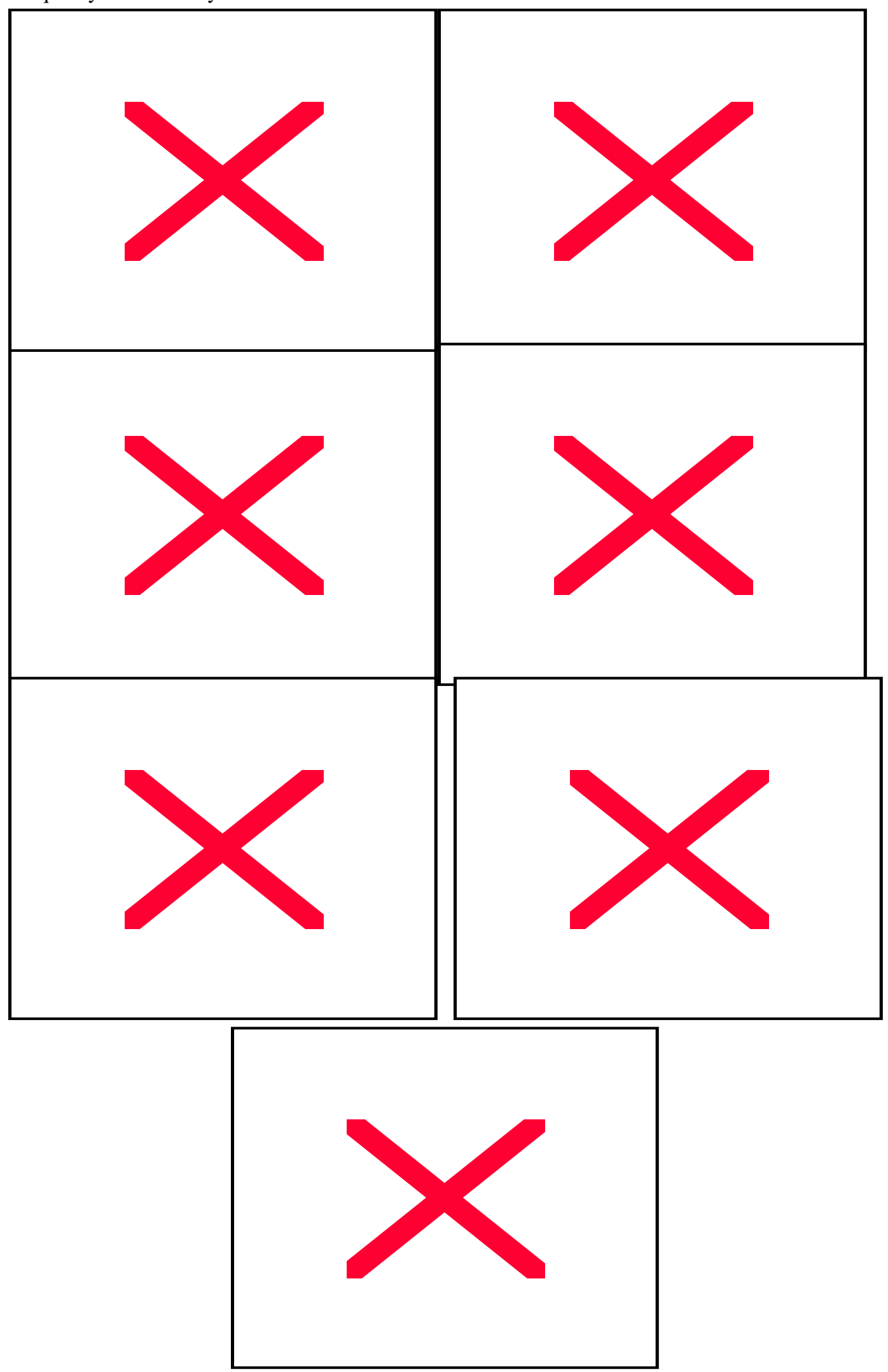
Table 1

Measures of quality practices

\section{Exploratory factor analysis for supplier and internal quality assurance practices}

\begin{tabular}{|c|c|c|c|c|c|}
\hline & Factor 1 & Factor 2 & Factor 3 & Factor 4 & Factor 5 \\
\hline Eigenvalue & 4.909 & 1.689 & 1.556 & 1.235 & 1.058 \\
\hline $\begin{array}{l}\text { Frequent meetings and communications with } \\
\text { suppliers (at least one a fortnight) }\end{array}$ & .101 & -.152 & .732 & -.199 & -.088 \\
\hline Single sourcing $^{1}$ & .088 & .202 & .654 & .183 & .015 \\
\hline Long-term contracts with suppliers $^{1}$ & -.116 & .228 & .600 & -.113 & -.224 \\
\hline $\begin{array}{l}\text { Programmes devoted to improving the relationship } \\
\text { with suppliers }{ }^{1}\end{array}$ & -.078 & .697 & -.011 & -.145 & -.251 \\
\hline Suppliers are assisted to resolve their problems ${ }^{1}$ & .130 & .838 & .081 & .057 & .121 \\
\hline Willingness to increase co-operation with suppliers ${ }^{1}$ & -.030 & .811 & .073 & -.075 & .101 \\
\hline $\begin{array}{l}\text { Suppliers are selected according to quality and } \\
\text { reliability dimensions as well as the price }\end{array}$ & -.013 & .070 & .030 & -.804 & .061 \\
\hline $\begin{array}{l}\text { Faults are controlled and penalised and the renewal of } \\
\text { contracts depends on that control }\end{array}$ & 195. & .127 & .062 & -.701 & .067 \\
\hline $\begin{array}{l}\text { Suppliers are approved, as a minimum requirement, } \\
\text { to ISO9001/2 }{ }^{1}\end{array}$ & -.035 & -.038 & .020 & -.724 & -.229 \\
\hline Suppliers design and develop components ${ }^{1}$ & .008 & -.079 & .030 & -.028 & -.900 \\
\hline $\begin{array}{l}\text { Suppliers actively participate in product } \\
\text { development }{ }^{1}\end{array}$ & .145 & -.019 & .080 & -0.47 & -.761 \\
\hline Statistical Quality Control $^{2}$ & .316 & .301 & -.296 & -.306 & -.061 \\
\hline Quality circles, group working $^{2}$ & .689 & .149 & -.214 & .030 & -.272 \\
\hline Continuous improvement process $^{2}$ & .765 & .155 & .037 & -.121 & .056 \\
\hline Preventive maintenance programmes ${ }^{2}$ & .819 & -.130 & .099 & -.212 & .133 \\
\hline Multi-skilled workers $^{2}$ & .655 & -.031 & .120 & .149 & -.176 \\
\hline
\end{tabular}

Implementation of Internal Quality Assurance Practices $=$ Factor 1

Implementation of Supplier Quality Assurance Practices = Factor 2 + Factor 3 - Factor 4 - Factor 5

${ }^{1}$ Items measured as the percentage of supplies to which the practice is applied. Six-point scales were used: 1 (none), 2 (few, 1-25\%), 3 (less than half, 2550\%), 4 (more than half, 50-75\%), 5 (almost all, 75-100\%), 6 (all, 100\%)

${ }^{2}$ Items measured with a six-point scale of implementation: from 1 (not at all) to 6 (intensively) 
Table 2

Measures of determinant factors

\begin{tabular}{|c|c|}
\hline \multicolumn{2}{|c|}{ Exogenous Factors } \\
\hline \multicolumn{2}{|l|}{ PRODUCT } \\
\hline $\begin{array}{l}\text { Technological } \\
\text { complexity }\end{array}$ & $\begin{array}{l}\text { Percentage of components that are technologically complex and require } \\
\text { experienced, well-trained and competent manufacturers }\end{array}$ \\
\hline Essentiality $^{1}$ & $\begin{array}{l}\text { Percentage of components and materials without which some or all the } \\
\text { production processes would be stopped }\end{array}$ \\
\hline Global cost & Percentage of the total cost of final products due to purchased components \\
\hline \multicolumn{2}{|l|}{ COMPANY } \\
\hline Size & Number of employees \\
\hline Internationalisation & $\begin{array}{l}\text { Binomial variable: (1) if the company belongs to an international group or } \\
\text { has foreign plants, (0) otherwise }\end{array}$ \\
\hline \multicolumn{2}{|l|}{ SUPPLIERS } \\
\hline Size $^{1}$ & $\begin{array}{l}\text { Percentage of components supplied by companies with more than } 100 \\
\text { employees }\end{array}$ \\
\hline Specialisation $^{1}$ & $\begin{array}{l}\text { Percentage of components supplied by companies completely dedicated to } \\
\text { the production of automotive components }\end{array}$ \\
\hline
\end{tabular}


Table 3

Measure of supply operational results

\begin{tabular}{|l|c|}
\hline & Loadings \\
\hline Design of products & 0.644 \\
\hline Time required to launch new products (INVERSE SCALE) & 0.332 \\
\hline Capacity to respond to customers request & 0.632 \\
\hline Quality of the final products & 0.663 \\
\hline Stock level of purchased products (INVERSE SCALE) & 0.436 \\
\hline $\begin{array}{l}\text { Supply costs (e.g. administrative, inspection, stock, supply cuts, etc.) (INVERSE } \\
\text { SCALE) }\end{array}$ & 0.546 \\
\hline Problems and misunderstandings with suppliers (INVERSE SCALE) & 0.628 \\
\hline Ability and capacity to co-ordinate activities with suppliers & 0.629 \\
\hline \multicolumn{1}{|c|}{ Cronbach $\boldsymbol{\alpha}: 0.7007$} & $33.04 \%$ \\
\hline
\end{tabular}

${ }^{1}$ Items measured as the relative position of the company with respect to their competitors. Five-point scales were used:

1 (very inferior), 2 (somewhat inferior), 3 (equal), 4 (somewhat superior), 5 (very superior). 
Table 4

Relationships between determinant factors

\begin{tabular}{|c|c|c|c|c|c|c|}
\hline & $\begin{array}{l}\text { Technological } \\
\text { complexity }\end{array}$ & Essentiality & $\begin{array}{ll}\begin{array}{l}\text { Value } \\
\text { purchases }\end{array} & \text { of } \\
\end{array}$ & Company size & Supplier size & $\begin{array}{l}\text { Supplier } \\
\text { specialisation }\end{array}$ \\
\hline Technological Complexity & - & & & \multirow{2}{*}{\multicolumn{3}{|c|}{ Spearman correlation tests }} \\
\hline Essentiality & $.254^{\star \star}$ & - & & & & \\
\hline Value of purchases & .080 & $.169 *$ & - & & & \\
\hline Company size & $.218^{\star \star}$ & .029 & -.078 & - & & \\
\hline Supplier size & .081 & .095 & $.414^{\star \star}$ & .146 & - & \\
\hline Supplier specialisation & $.262^{\star \star}$ & .126 & .150 & .144 & .066 & - \\
\hline $\begin{array}{l}\text { Company internationalisation } \\
\text { (ANOVA TESTS) }\end{array}$ & $\mathrm{F}=5.208^{*}$ & $F=1.521$ & $\mathrm{~F}=17.495^{\star \star}$ & $\mathrm{F}=4.004^{*}$ & $\mathrm{~F}=11.457^{\star \star *}$ & $\mathrm{~F}=7.748^{\star \star}$ \\
\hline
\end{tabular}


Table 5

Relationship between supplier quality assurance and factors in the model

\begin{tabular}{|c|c|c|c|c|c|c|c|}
\hline & $\begin{array}{l}\text { Technological } \\
\text { complexity }\end{array}$ & Essentiality & \begin{tabular}{|ll}
$\begin{array}{l}\text { Value } \\
\text { purchases }\end{array}$ & of \\
\end{tabular} & Company size & Supplier size & $\begin{array}{l}\text { Supplier } \\
\text { specialisation }\end{array}$ & $\begin{array}{l}\text { Company } \\
\text { internationalisation }\end{array}$ \\
\hline $\begin{array}{l}\text { Correlation with supplier } \\
\text { quality assurance } \\
\text { (PEARSON TESTS) }\end{array}$ & $0.428^{\star \star}$ & $0.276^{\star \star}$ & $0.202^{*}$ & 0.149 & $0.208^{* *}$ & $0.407^{* \star}$ & \\
\hline $\begin{array}{l}\text { Comparison of supplier } \\
\text { quality assurance means } \\
\text { (ANOVA TESTS) }\end{array}$ & $F=7.918^{* *}$ & $F=4.981^{* *}$ & $F=3.551^{*}$ & $F=2.685^{+}$ & $F=1.350$ & $F=6.335^{\star \star}$ & $\mathrm{F}=22.671^{\star *}$ \\
\hline
\end{tabular}


Table 6

Stepwise regression for supplier quality assurance

\begin{tabular}{|r|c|c|c|}
\hline & First step & Second step & Third step \\
& $\beta$ & $\beta$ & $\beta$ \\
& $(\mathrm{t})$ & $(\mathrm{t})$ & $(\mathrm{t})$ \\
\hline Technologic complexity & .428 & .402 & .371 \\
& $(5.798)^{* *}$ & $(5.971)^{* *}$ & $(5.544)^{* *}$ \\
Suppliers specialisation & & .380 & .320 \\
Company & & $(5.634)^{* *}$ & $(4.599)^{* *}$ \\
internationalisation & & & .191 \\
$\mathrm{R}^{2}$ & 0.183 & & $(4.703)^{* *}$ \\
$\mathrm{~F}$ & $33.613^{* *}$ & $36.122^{* *}$ & $27.536^{* *}$ \\
& & & \\
\hline
\end{tabular}

** $\mathrm{p}=0.01$

$* \mathrm{p}=0.05$ 
Table 7

Multiple regression for supply operational results of the purchasing function

\begin{tabular}{|c|c|c|}
\hline & $\begin{array}{c}\text { Supply Operational } \\
\text { Results } \\
\beta \\
\text { (t) } \\
\end{array}$ & $\begin{array}{c}\text { Supply Operational } \\
\text { Results } \\
\beta \\
(\mathrm{t}) \\
\end{array}$ \\
\hline $\begin{array}{r}\text { Supplier quality } \\
\text { assurance implementation }\end{array}$ & $\begin{array}{c}0.402 \\
(5.401)^{* *}\end{array}$ & $\begin{array}{c}0.311 \\
(4.040)^{* *}\end{array}$ \\
\hline $\begin{array}{r}\text { Internal quality assurance } \\
\text { implementation }\end{array}$ & & $\begin{array}{c}0.260 \\
(3.374)^{* *}\end{array}$ \\
\hline Company Size & $\begin{array}{c}0.122 \\
(1.639)\end{array}$ & $\begin{array}{c}0.095 \\
(1,316)\end{array}$ \\
\hline $\mathrm{R}^{2}$ & 0.192 & 0.249 \\
\hline $\bar{F}$ & $17.648 * *$ & $16,379 * *$ \\
\hline
\end{tabular}

